\title{
Morphological Complexity and Conceptualization: The Human Body
}

The arbitrariness of the linguistic sign (,l'arbitraire du signe") and especially of the word is one of the fundamental assumptions in Saussure's Cours de Linguistique Générale:

Le lien unissant le signifiant au signifié est abitraire, ou encore, puisque nous entendons par signe le total résuitant de l'association d'un signifiant à une signifié, nous pouvons dire plus simplement: $\underline{\text { le }}$ signe linguistique est arbitraire [...]; nous voulons dire qu'il est immotivé, c'est-à-dire arbitraire par rapport au signifié, avec lequel il n'a aucune attache naturelle dans la réalité. (Saussure 1915: 100-01) ${ }^{1}$

In the one hundred years since the publication of the Cours, linguistic investigation has modified this assumption, showing that some features of linguistic structure in phonology, morphology and syntax are motivated. In this context, scholars of Natural Theory have contributed important results, such as Stampe, Mayerthaler, Wurzel, Dressler, Haiman and many others. By contrast, the lexicon is still considered unpredictable and arbitrary:

The fact that English ear means what it does and functions as a noun does not follow from any general property of the language [...] This fact is completely 'exceptional' in the sense that there is nothing else about the language from which it could have been predicted. Such arbitrariness is typical of the lexicon, which is to this extent the repository of what is idiosyncratic and unpredictable about linguistic forms.

(Anderson 1985: 3-4)

Anderson's remark on the arbitrariness of the lexicon is true in the sense that a lexical unit does not result from any other structural property of a given language. However the motivation for certain lexical structures is to be found not in internal, but in external motivations, more precisely, in cognitive factors underlying which motivates the linguistic expression. The supposed arbitrariness of lexical items may be one of the reasons why the relationship between lexical semantics and morphology is little investigated. As Levin and Hovav (1998) note:

The relation between lexical semantics and morphology has not been the subject of much study. This may be surprising, since a morpheme is often viewed as a minimal Saussurian sign relating form and meaning: it is a concept with a phonologically composed name. [...] Since morphology is the study of the structure and derivation of complex signs, attention could be focused on the semantic side (the composition of complex concepts) and the structural side (the composition of the complex names for the concepts) and the relation between them.

(Levin/Hovav 1998: 248)

In this squib, I want to argue that the morphological structure of words is, at least to some extent, motivated. As an example I have choosen the partonomic (and for the less

1 Emphasis in the original text. 
part taxonomic) nomenclature ${ }^{2}$ of the human body. While important work by Brown et alii (1973), Anderson (1978) and Schladt (1997) exists on this topic, these analyses focus on the conceptualization of body-parts and their semantics, but not on their morphological representation. ${ }^{3}$

In the following, I want to check two predictions about the morphological complexity of lexical items denoting parts of the human body. The first assumption is that the most canonical body-parts ${ }^{4}$ are always expressed by mono-lexematic items. The second one consists in the assumption that body-parts of the lowest levels in the hierarchy are always morphologically complex..$^{5} \mathrm{~A}$ set of six body-parts has been analysed in 27 languages. The set consists of two canonical (HEAD and EAR) and of one from the lowest level of the hierarchy (TOENAIL). For this I have adopted a sample from Schladt (1997) and a small one compiled by myself. ${ }^{6}$ In table 1 are listed the results for 18 languages spoken in Kenya (Cushitic, Nilotic and Bantu):

table 1

\begin{tabular}{|l|c|c|}
\hline concept & mono-lexematic & complex construction \\
\hline HEAD & 18 & 0 \\
\hline EAR & 18 & 0 \\
\hline SPINAL COLUMN & 8 & 10 \\
\hline THUMB & 3 & 15 \\
\hline NIPPLE & 1 & 17 \\
\hline TOENAIL & 0 & 18 \\
\hline
\end{tabular}

In table 2 are listed the results of a sample of other nine languages (German, KhalkhaMongolian, Upper Sorbian, Bahasa Indonesian, Hungarian, Turkish, Vietnamese, Finnish and English):

table 2

\begin{tabular}{|l|c|c|}
\hline concept & mono-lexematic & complex construction \\
\hline HEAD & 9 & 0 \\
\hline EAR & 9 & 0 \\
\hline THUMB & 5 & 4 \\
\hline NIPPLE & 4 & 5 \\
\hline SPINAL COLUMN & 2 & 7 \\
\hline TOENAIL & 0 & 9 \\
\hline
\end{tabular}

2 Partonomy refers to the relationship , $\mathrm{x}$ is part of $\mathrm{y}^{\prime}$ and ,y is part of z' (e.g. Tisch, Tischbein, Tischbeinende). In contrast to taxonomy, in partonomic relations, switching beween the different levels of the hierarchy is not possible. For example, you can say a toenail is part of the toe, but not the toenail is part of the leg. Body-part partonomies contain normally five levels (Brown et al. 1973).

3 Matisoff (1978) includes phonological aspects.

4 I adapt 'canonical' from Schladt (1997: 69-74) who prefers this term to 'prototypical' speaking of body-parts.

5 A third assumption, not emprically cxamined in this squib, is the prediction that the majority of the terms for the lower half of the body are morphologically more complex compared to those of the upper half. This results from the conceptual hierarchy UP $\rightarrow$ DOWN: "oben ist unmarkiert - unten ist markiert" (Schladt 1997: 81).

6 The criteria for a representative sample of languages for the typology of lexical semantics need not follow the same principles as for grammatical typology, i.e. geographical distribution, genetic relationship and grammatical structure (see Koch/Steinkrüger in press). 
The results show that the expressions for HEAD and EAR are always mono-lexematic, whereas the expression for TOENAIL is always morphologically complex. The non- or less canonical body-parts in the middle sphere show a mixed behaviour. This result exactly shows a correspondence between conceptual markedness and morphological complexity.

With some examples taken from the nomenclature of the human body, I have demonstrated that the morphological complexity of the lexicon is not totally arbitrary. I suggest, this has an external, i.e. non-linguistic, motivation, more precisely from human cognition. Further investigation may go into more detail.

\section{References}

Anderson, Elaine S. (1978): Lexical Universals of Body-Part Terminology. In: Greenberg, Joseph $H$. et al. (eds.): Universals of Human Language. Volume 3: Word Structure. Stanford/Ca.: Stanford University Press. 335-368

Anderson, Stephen R. (1985): Typological distinctions in word formation. In: Shopen, Timothy (ed.): Language Typology and syntactic description. Volume III: Grammatical Categories and the Lexicon. Cambridge; etc.: Cambridge University Press. 3-56

Brown, B.; Breedlove, D.; Raven, P. (1973): General principles of classification and nomenclature in folk biology. American Anthropologist 75. 214-242

Koch, Peter; Steinkrüger, Patrick O. (in press): Poligenesi lessicale e dati ,cmpirici'. To appear in: Atti del XXXIII Congresso Internazionale della Società Linguistica Italiana (Napoli 1999)

Levin, Beth; Rappaport Hovav, Malka (1998): Morphology and Lexical Semantics. In: Spencer, Andrew; Zwicky, Arnold M. (eds.): The Handbook of Morphology. Oxford: Blackwell. 248-271

Matisoff, James A. (1978): Variational semantics in Tibeto-Burman: the 'organic' approach to linguistic comparison. Philadelphia: Institute for the Study of Human Issues

Saussure, Ferdinand (1915): Cours de Linguistique Générale. Edition by Tullio de Mauro. Paris: Payot, 1984

Schladt, Mathias (1997): Kognitive Strukturen von Körperteilvokabularien in kenianischen Sprachen, Köln: Universität, Institut für Afrikanistik

Patrick Oliver Steinkrüger

Zentrum für allgemeine Sprachwissenschaft,

Typologie und Universalienforschung

Jägerstr. 10-11

10117 Berlin

Germany

steinkrueger@zas.gwz-berlin.de 